\title{
Prevalence of enteroparasitic infections and related hormonal and immunological repercussions that may compromise students' physical performance
}

\author{
Nunez, P.R.M. ${ }^{1,2}$, Honorio-França, A.C. ${ }^{3}$, Geiger, S.M. ${ }^{2}$, Guedes, M. ${ }^{2}$, Fagundes, D.L.G. ${ }^{3}$, \\ Magalhães, A.M. ${ }^{3}$, Gomes, M.A. ${ }^{2}$ and França, E.L. ${ }^{3^{*}}$ \\ ${ }^{1}$ Education Faculty, Federal University of Mato Grosso do Sul - Campo Grande, MS, Brazil \\ ${ }^{2}$ Department of Parasitology, Institute of Biological Sciences, Federal University of Minas Gerais, \\ Belo Horizonte, Minas Gerais, Brazil \\ ${ }^{3}$ Institute of Biological and Health Science, Federal University of Mato Grosso, Barra do Garças, MT, Brazil \\ *Corresponding author e-mail: dr.eduardo.franca@gmail.com \\ Received 5 November 2018; received in revised form 31 March 2020; accepted 1 April 2020
}

\begin{abstract}
The aim of this study was to evaluate the prevalence of enteroparasitic infections in students and their hormonal and immunological repercussions on physical development. Students of basic education of both sexes were evaluated. Parasitological stool tests were performed using the Hoffman and Kato-Katz methods. The students were divided into two groups: a control group (negative parasitological examination, $\mathrm{N}=25$ ) and an infected group (positive parasitological test, $\mathrm{N}=25$ ). Anthropometric variables (height, weight, and $\mathrm{BMI}$ ), concentrations of hormones (melatonin and cortisol), cytokine/chemokine levels (IL-1 $\beta$, IL-6, IL-8, IL-10, IL-12, IL-17 and TNF- $\alpha$ ) and physical performance (aerobic capacity, upper- and lower-limb muscle strength and abdominal performance) were evaluated. The prevalence of parasitic infection among the students was $7.98 \%$. No anthropometric differences were observed among the groups. IL- 2 and TNF- $\alpha$ levels were higher and IL- 8 levels were lower in serum from students who were positive for parasitic infection. Serum from students who were positive for parasitic infection showed higher levels of melatonin than that from parasitenegative students. No differences were observed in cortisol levels. Students who were positive for parasitic infection presented greater lower-limb strength and lower abdominal performance than parasite-negative students. In the parasitic infection group, IL-12 was positively correlated with melatonin. In the parasitic infection group, IL-8 showed a positive correlation with aerobic capacity, while IL-17 and TNF- $\alpha$ showed a positive correlation with abdominal performance. These data suggest that parasitic infections determine the profile of inflammatory cytokines and that melatonin may be involved in the control of this process to minimize tissue damage. Additionally, students' difficulty in practising physical exercises can be an indication of enteroparasitic infection.
\end{abstract}

\section{INTRODUCTION}

Despite advances in the control of infant morbidity and mortality and in basic care, there are still several health problems in practically all urban areas of Brazil, with greater intensity among the vulnerable populations of the peripheral territories. The lack of infrastructure increases the epidemiological complexity, favouring the emergence of new diseases and the resurgence of old endemics, including parasitic infections (Hijjar et al., 2005).

Weight-height deficit and anaemia are the main causes of morbidities associated with childhood enteroparasitic infections. Parasitic infections may compromise nutritional status due to reduced food intake and/or increased nutrient loss (Ostan et al., 2007; Araújo Filho et al., 2011). Thus, helminth and protozoal infections have been associated with a number of adverse 
health consequences, including inadequate growth and decreased physical performance (Lander et al., 2012).

Physical exercise causes functional changes in the immune system and may induce an inflammatory response by increasing serum levels of IL-1, TNF- $\alpha$ and IL-6, followed by the release of antiinflammatory cytokines, such as IL-10. The type, duration and intensity of exercise greatly influence the post-exercise cytokine response profile. The release of IL-1 appears to be most sensitive to exercise intensity, whereas TNF- $\alpha$ and IL- 6 are most sensitive to exercise duration (Ferreira, 2009).

The cytokine IL-6, along with the cytokines IL-1, IL-4, IL-5, IL-10 and IL-13, seems to determine the pattern of inflammatory responses, increased antibody production and marked eosinophil activation (Gleeson, 2006). Inflammation is considered a highly beneficial and necessary process in regular and systematized physical training because, in conjunction with the action of hormones, it is responsible for the regeneration and repair of damaged structures (Zaldivar et al., 2006).

The hormones cortisol (produced by the adrenal gland) and melatonin (secreted by the pineal gland) have been reported to act on immune mechanisms involved in the parasite-host relationship, especially during parasitic infections. These hormones can modulate the immune response profile, as the levels of these hormones modulate cytokine production (Martinez-Bakker et al., 2015; Quintanar-Stephano et al., 2015).

Melatonin can influence both humoral and cellular responses as well as the production of mediators. The actions of this hormone have been related to several pathologies, including infections and inflammation (Carrillo-Vico et al., 2004; Santello et al., 2007; Santello et al., 2008a; Santello et al., 2008b). However, the effects of this hormone on individuals who practise physical exercise are still only partially understood.

However, there is controversy in the literature on the influence of enteroparasitic infections on physical aptitude. Some authors report that children with parasitic infection are strongly affected (Yap et al., 2012) and that diarrhoea caused by helminth infection influences the development of physical aptitude (Guerrant et al., 1999). Additionally, after treatment, there is an improvement in physical capacity (Stephenson et al., 1990; Stephenson et al., 1993). However, other studies suggest that enteroparasitic infections do not influence physical activity (Muller et al., 2011).

However, no data have been found in the literature demonstrating that enteroparasitic infections can influence physical performance through effects on hormones and cytokines. Considering that parasitic infections in organisms can cause several neuroimmunoendocrine alterations, the aim of this study was to evaluate the prevalence of enteroparasitic infections and their possible hormonal and immunological repercussions on the physical development of students.

\section{MATERIALS AND METHODS}

The prevalence and load of enteroparasites among students and the correlations among anthropometric measures and immunological and hormonal factors were evaluated in a cross-sectional study.

This study was approved by the Federal University of Minas Gerais Research Ethics Committee (CAAE 19354513.3.0000.5149), and parents or legal guardians gave informed written consent before of students participating in the experiment.

\section{Subjects}

The study was carried out on a population composed of elementary school students of both sexes aged 5 to 14 years with medium age of 9,7 years and enrolled in public educational institutions of the municipality of Jaboticatubas, MG, Brazil. Among the basic sanitation conditions of the students, only $13.2 \%$ had a sewage system, but without treatment. The majority declared to use a septic tank for domestic sewage (73.6\%) and were supplied by a public treated water network (63.3\%). The disposal of household waste was the municipal responsibility 
(52.8\%); and $41.5 \%$ of students affirm to bury or burn household waste.

The population of elementary school students aged 5 to 14 years in Jaboticatubas is 1,294 individuals. According to the sample calculation by the OpenEpi2 program (Version 2.3.1, with a 95\% confidence level), the minimum sample number for the study was 207 children, but in this study, 313 children were initially examined. Subjects within the defined age range were randomly selected. The students were submitted to parasitological exams of faeces, and 25 (13 female and 12 male) of a total of 313 students had parasitic infection.

After parasitological evaluation, 25 students (13 female and 12 male) with negative parasitological examination were randomly chosen to compose the control group. Thus, the students were divided into two groups, the control group (negative parasitological examination, $\mathrm{N}=25$ ) and the infected group (positive parasitological test, $\mathrm{N}=25$ ), for quantification of hormones and cytokines and evaluation of physical performance. After performing the physical tests and undergoing blood collection, all infected students were referred for specific treatment.

\section{Inclusion and Exclusion Criteria}

The inclusion criteria were as follows: (a) age of 5-14 years; (b) school children enrolled in the public school system; (c) signed a consent form and (d) not using any antiparasitic agents during the collection period for faecal material and blood samples. School children who presented cognitive, psychiatric or behavioural disorders were excluded.

\section{Stool examination}

For stool collection, glass containers that had been previously labelled with the name, age and grade of each student were distributed to the participants the day before collection. The samples were collected the next day. Stool samples were subjected to two methods: the spontaneous sedimentation method (Hoffman et al., 1934) and the KatoKatz Method (Kataz et al., 1972) using a Helm
Test Kit (Bio Manguinhos, Fiocruz, Rio de Janeiro, Brazil).

\section{Blood sampling}

Blood samples were always taken in the morning. Blood (10 mL) was collected from each subject in tubes without anticoagulant. We centrifuged the blood samples at $300 \times g$ for 15 min until serum separation. Serum samples were stored individually in aliquots of $500 \mu \mathrm{L}$ at $-80^{\circ} \mathrm{C}$ for further analysis.

\section{Melatonin determination by the immuno- enzymatic method}

Melatonin was extracted from serum by affinity chromatography, concentrated in speed vacuum and measured with a commercial ELISA kit (IBL, Hamburg, Germany). The concentration was measured by absorbance in a spectrophotometer equipped with a plate-reader and $405 \mathrm{~nm}$ filter. Melatonin levels were calculated based on the standard curve in $\mathrm{pg} / \mathrm{mL}$.

\section{Cortisol determination by the immuno- enzymatic method}

Cortisol levels were determined from serum using a commercial ELISA kit (Accu Bind ELISA kit, IBL, Hamburg, Germany). The concentration was measured by absorbance in a spectrophotometer with a $405 \mathrm{~nm}$ filter. Cortisol levels were calculated based on the standard curve in $\mu \mathrm{g} / \mathrm{dL}$.

\section{Quantification of cytokines}

Blood samples were collected, and the serum obtained was stored at $-80^{\circ} \mathrm{C}$ prior to analyses. The samples were thawed, and cytokines (IL-1 $\beta$, IL-6, IL-8, IL-10, IL-12, IL-17 and $\mathrm{TNF}-\alpha$ ) were measured by cytometric bead array (CBA, BD Biosciences, USA) according to the manufacturer's instructions. A flow cytometer was used for these analyses (FACSCalibur, BD Biosciences, USA). The data were analysed using FCAP Array 1.0 software (CBA, BD Biosciences, USA).

\section{Physical growth and motor performance evaluation}

Body mass: Total body mass was determined following the recommendations of Gordon 
et al. (1991) for children from 5 to 10 years old and from 10 to 15 years old using a digital scale with a range of 0 to $150 \mathrm{~kg}$ and a precision of $200 \mathrm{~g}$.

Height: The height of the individuals in the orthostatic position was determined following the procedures of Gordan et al. (1991) for children from 5 to 10 years old and from 10 to 15 years old using a wooden stadiometer graduated in millimetres with a range of 0 to $2.50 \mathrm{~m}$.

\section{Motor performance evaluation}

Flexibility test: To measure the muscular power of the upper limbs, the flexibility of the dorso-lumbar region was evaluated using a modified wooden box with dimensions of $30.5 \times 30.5 \times 30.5 \mathrm{~cm}$ and a surface of $70 \mathrm{~cm}$ following the modified procedure recommended by Hoeger et al. (1992).

Abdominal test: The strength of the abdominal muscles was evaluated on a mattress with hands at the nape of the neck and the knees semi-flexed (both sexes) for one minute using a precision Casio chronometer (1/100 sec.) following the recommendations of de Soares et al. (1983).

Standing distance jump test: The muscular power of the lower limbs was evaluated on a soft flat surface; the distance jumped was measured following the recommendations proposed by Soares $e t$ al. (1983) with a tape measure with an accuracy of $0.1 \mathrm{~cm}$ and a range of 0 to $3 \mathrm{~m}$.

Speed test: To evaluate the aerobic capacity, the time to run a distance of $20 \mathrm{~m}$ was evaluated. A precision Casio chronometer $(1 / 100 \mathrm{sec})$ was used; the timer was started the moment the individual took the first step from the start line and was stopped at the moment the individual passed the finish line.

\section{Statistical analysis}

The means and their respective standard deviations (SDs) of hormone levels, cytokine concentrations and physical performance were calculated for the groups of parasitized and unparasitized school children, and Student's t-test was used to verify differences in the means between those groups. Correlations among cytokines, hormones and physical performance were evaluated used Pearson's linear correlation test. Statistical significance was considered for a p-value lower than $0.05(p<0.05)$.

\section{RESULTS}

The prevalence of parasitic infection among the students studied was $7,98 \%$. Among the 25 parasitized students, Schistosoma mansoni was the most prevalent parasite (80\%), while the others were infected (20\%) by Enterobius vermicularis, Ancylostomatidae spp., or Ascaris lumbricoides. Table 1 presents the general characteristics and anthropometric data of the students. Other than the presence of parasites, there were no differences between the groups.

Table 2 shows the serum cytokine levels in the students. IL-12 and TNF- $\alpha$ levels were higher in serum from students positive for

Table 1. Anthropometric data of school children with parasitic infection

\begin{tabular}{lcc}
\hline \multirow{2}{*}{ Parameters } & \multicolumn{2}{c}{ Parasitic Infection } \\
\cline { 2 - 3 } & Negative & Positive \\
\hline Age (years) & $9.8 \pm 1.1$ & $9.9 \pm 0.8$ \\
Body Mass (kg) & $36.5 \pm 8.6$ & $36.3 \pm 7.1$ \\
Stature (cm) & $141 \pm 10$ & $143 \pm 10$ \\
BMI & $17.7 \pm 2.2$ & $17.4 \pm 2.4$ \\
Eutrophic & $76 \%$ & $70 \%$ \\
Overweight & $20 \%$ & $20 \%$ \\
Obese & $4 \%$ & $10 \%$ \\
\hline
\end{tabular}

$\mathrm{BMI}=$ body mass index.

Table 2. Cytokine concentrations $(\mathrm{pg} / \mathrm{mL})$ in the serum of students with parasitic infection

\begin{tabular}{lcc}
\hline \multirow{2}{*}{ Cytokines } & \multicolumn{2}{c}{ Parasitic Infection } \\
\cline { 2 - 3 } & Negative & Positive \\
\hline IL-1 $\beta$ & $7.5 \pm 3.1$ & $9.1 \pm 2.9$ \\
IL-6 & $4.2 \pm 2.0$ & $3.9 \pm 1.3$ \\
IL-8 & $115.0 \pm 83.3$ & $26.7 \pm 15.5^{*}$ \\
IL-10 & $5.6 \pm 1.1$ & $5.9 \pm 1.3$ \\
IL-12 & $7.6 \pm 4.4$ & $45.7 \pm 21.2^{*}$ \\
IL-17 & $22.5 \pm 6.9$ & $31.0 \pm 12.1$ \\
TNF- $\alpha$ & $5.1 \pm 1.9$ & $20.5 \pm 8.6^{*}$ \\
\hline
\end{tabular}

The results represent the mean and SD of 25 different individuals. *indicates intergroup differences $(\mathrm{p}<0.05)$. 
parasitic infection than in that from parasitenegative students, whereas IL-8 levels were lower in parasite-positive students than in parasite-negative students. The IL-1 $\beta$, IL-6, IL-10 and IL-17 levels were similar between the groups.

Serum from students who were positive for parasitic infection showed higher levels of melatonin than that of the students negative for parasitic infection. The cortisol levels were similar between the groups studied (Figure 1).

There was no difference in aerobic capacity between school children with parasitic infection and non-parasitized school children. School children positive for parasitic infection presented higher strength of the lower limbs than did the unparasitized children, while the strength of the upper limbs of the school children was similar between the groups. There was a reduction in abdominal performance in school children with parasitic infection.

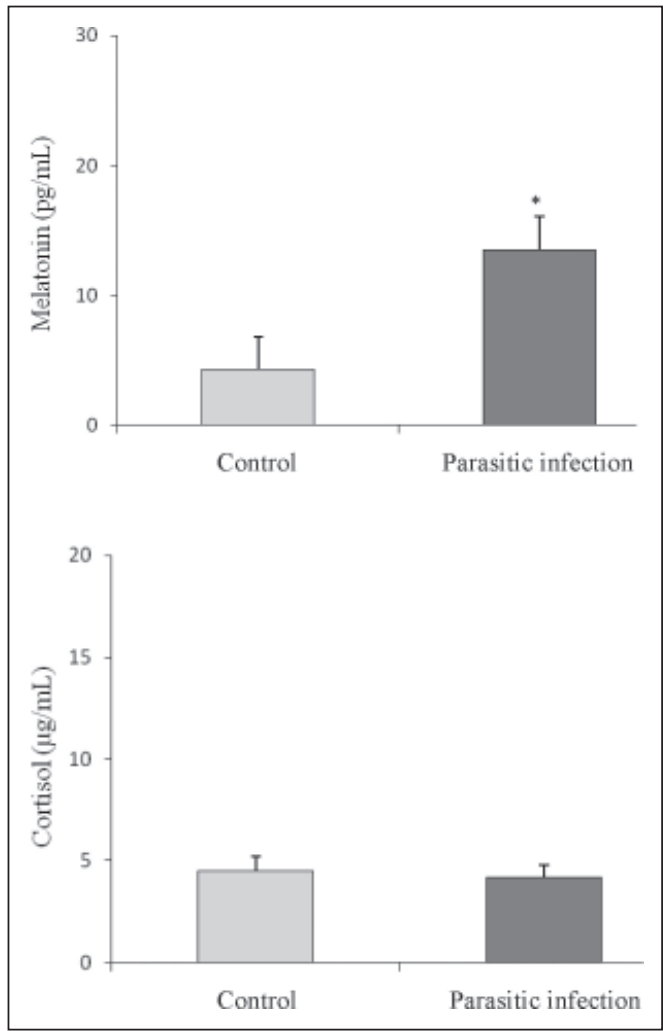

Figure 1. Melatonin (pg/mL) and cortisol (pg/mL) levels in serum from school children. * Statistical difference between the groups $(\mathrm{P}<0.05)$.
Correlations among cytokine and hormone levels and physical performance were evaluated with Pearson's test. The control group exhibited a negative correlation between melatonin levels and the levels of IL- $1 \beta$ and IL- 6 , whereas cortisol showed a negative correlation with IL-17. In the parasitic infection group, IL-12 levels were positively correlated with melatonin levels (Table 3).

Regardless of the presence of parasitic infection, none of the physical performance parameters evaluated correlated with the serum levels of hormones (melatonin and cortisol) in the school children (Table 4).

Analysis of correlations between physical performance and cytokine/ chemokine levels showed that in the control group, there was a positive correlation between IL-1 and upper-limb strength. The chemokine IL-8 showed a positive correlation with abdominal performance, and IL-12 presented a negative correlation with lower-limb strength (Table 5). In the parasitic infection group, the chemokine IL-8 showed a positive correlation with aerobic capacity, while IL-17 and TNF- $\alpha$ showed a positive correlation with abdominal performance. However, with respect to IL-6 and IL-10 levels, no correlations $(p>0.05)$ were found with physical performance (Table 5).

\section{DISCUSSION}

Parasitic infections, especially in developing countries, constitute a serious public health problem (Ostan et al., 2007; Basso et al., 2008), and children are more vulnerable to intestinal parasites than are other age groups (Montresor et al., 2002). This study describes the serum cytokine and hormone concentrations and the physical performance of children infected with enteroparasites and examine the correlation between these variables.

The prevalence of parasitic infection depends on external environmental factors and factors inherent to individuals (Frei $e t$ al., 2008). In this study, the majority of school children were residents of rural areas and despite the supply of treated water and 
Table 3. Correlations between cytokines/chemokines and the hormones melatonin and cortisol in serum from school children

\begin{tabular}{|c|c|c|c|c|}
\hline \multirow{2}{*}{$\begin{array}{l}\text { Cytokines/ } \\
\text { Chemokines }\end{array}$} & \multicolumn{2}{|c|}{ Melatonin } & \multicolumn{2}{|c|}{ Cortisol } \\
\hline & Control & $\begin{array}{l}\text { Parasitic } \\
\text { infection }\end{array}$ & Control & $\begin{array}{l}\text { Parasitic } \\
\text { infection }\end{array}$ \\
\hline IL- $1 \beta$ & $\begin{array}{c}r=-0.6272 \\
P=0.0092\end{array}$ & $\begin{array}{c}\mathrm{r}=-0.2150 \\
\mathrm{P}=0.4072\end{array}$ & $\begin{array}{c}\mathrm{r}=-0.2753 \\
\mathrm{P}=0.3020\end{array}$ & $\begin{array}{c}r=-0.1004 \\
P=0.7115\end{array}$ \\
\hline IL-6 & $\begin{array}{c}r=-0.5340 \\
P=0.0331\end{array}$ & $\begin{array}{l}\mathrm{r}=0.0795 \\
\mathrm{P}=0.7617\end{array}$ & $\begin{array}{l}\mathrm{r}=0.1734 \\
\mathrm{P}=0.5207\end{array}$ & $\begin{array}{l}\mathrm{r}=0.0682 \\
\mathrm{P}=0.8018\end{array}$ \\
\hline IL-8 & $\begin{array}{c}r=-0.0579 \\
P=0.8314\end{array}$ & $\begin{array}{l}\mathrm{r}=0.2167 \\
\mathrm{P}=0.4034\end{array}$ & $\begin{array}{c}r=-0.3380 \\
P=0.2003\end{array}$ & $\begin{array}{c}r=-0.4190 \\
P=0.8776\end{array}$ \\
\hline IL-10 & $\begin{array}{c}\mathrm{r}=-0.1367 \\
\mathrm{P}=0.6138\end{array}$ & $\begin{array}{l}\mathrm{r}=0.0823 \\
\mathrm{P}=0.7534\end{array}$ & $\begin{array}{l}\mathrm{r}=0.1736 \\
\mathrm{P}=0.5202\end{array}$ & $\begin{array}{c}\mathrm{r}=-0.3712 \\
\mathrm{P}=0.1569\end{array}$ \\
\hline IL-12 & $\begin{array}{c}\mathrm{r}=-0.2888 \\
\mathrm{P}=0.2779\end{array}$ & $\begin{array}{c}r=0.6254 \\
P=0.0303\end{array}$ & $\begin{array}{c}r=-0.0953 \\
P=0.7255\end{array}$ & $\begin{array}{c}r=-0.2238 \\
P=0.4048\end{array}$ \\
\hline IL-17 & $\begin{array}{c}\mathrm{r}=-0.2080 \\
\mathrm{P}=0.4395\end{array}$ & $\begin{array}{l}\mathrm{r}=0.2761 \\
\mathrm{P}=0.3850\end{array}$ & $\begin{array}{c}r=-0.5742 \\
P=0.0199\end{array}$ & $\begin{array}{c}\mathrm{r}=-0.3854 \\
\mathrm{P}=0.2159\end{array}$ \\
\hline TNF- $\alpha$ & $\begin{array}{c}\mathrm{r}=-0.3529 \\
\mathrm{P}=0.1799\end{array}$ & $\begin{array}{c}\mathrm{r}=-0.0778 \\
\mathrm{P}=0.7668\end{array}$ & $\begin{array}{l}\mathrm{r}=0.1946 \\
\mathrm{P}=0.4703\end{array}$ & $\begin{array}{l}\mathrm{r}=0.3766 \\
\mathrm{P}=0.1505\end{array}$ \\
\hline
\end{tabular}

Table 4. Correlations between physical performance and the hormones melatonin and cortisol in serum from school children

\begin{tabular}{lccccc}
\hline & \multicolumn{2}{c}{ Melatonin } & & \multicolumn{2}{c}{ Cortisol } \\
\cline { 2 - 3 } Physical Performance & Control & $\begin{array}{c}\text { Parasitic } \\
\text { infection }\end{array}$ & & Control & $\begin{array}{c}\text { Parasitic } \\
\text { infection }\end{array}$ \\
\cline { 2 - 5 } Aerobic capacity & $\mathrm{r}=0.3619 ;$ & $\mathrm{r}=0.0427 ;$ & & $\mathrm{r}=-0.2216 ;$ & $\mathrm{r}=0.2186 ;$ \\
& $\mathrm{P}=0.1683$ & $\mathrm{P}=0.8708$ & & $\mathrm{P}=0.4094$ & $\mathrm{P}=0.4159$ \\
Lower-limb strength & $\mathrm{r}=0.3164 ;$ & $\mathrm{r}=0.1752 ;$ & & $\mathrm{r}=0.0961 ;$ & $\mathrm{r}=-0.0247 ;$ \\
& $\mathrm{P}=0.2324$ & $\mathrm{P}=0.5013$ & & $\mathrm{P}=0.7232$ & $\mathrm{P}=0.9276$ \\
Upper-limb strength & $\mathrm{r}=-0.0538 ;$ & $\mathrm{r}=0.4060 ;$ & & $\mathrm{r}=-0.1825 ;$ & $\mathrm{r}=0.0351 ;$ \\
& $\mathrm{P}=0.8431$ & $\mathrm{P}=0.1058$ & & $\mathrm{P}=0.4986$ & $\mathrm{P}=0.8974$ \\
& $\mathrm{r}=0.2826 ;$ & $\mathrm{r}=-0.1496 ;$ & & $\mathrm{r}=-0.2143 ;$ & $\mathrm{r}=0.3286 ;$ \\
& $\mathrm{P}=0.2888$ & $\mathrm{P}=0.5666$ & & $\mathrm{P}=0.4255$ & $\mathrm{P}=0.2140$ \\
\hline
\end{tabular}

regular garbage collection, most still use a sewer for domestic sewage and bury or burn domestic waste, which may contribute to the persistence and prevalence of parasites in this community, that was $7.98 \%$. Among the infected students, $80 \%$ were infected by $S$. mansoni and $20 \%$ were infected by $E$. vermicularis, Ancylostomatidae spp., or A. Lumbricoides.

In parasitic infections, several effectors mechanisms of the immune system are activated that are capable of controlling infection (Moraes et al., 2015); these mechanisms generate inflammation that can be regulated by several biochemical signals, with cytokines being one of the most important mediators of this condition (Morais et al., 2015; Fagundes et al., 2016; Fujimori et al., 2017; Fagundes et al., 2018).

The immune response to helminth infection, such as $S$. mansoni infection, is a complex immune process, especially in the acute phase that depends on the intensity and severity of the disease (Araujo et al., 2004). 
Table 5. Correlations between cytokines/chemokines and the physical performance of school children

\begin{tabular}{|c|c|c|c|c|c|}
\hline $\begin{array}{c}\text { Cytokines/ } \\
\text { Chemokines }\end{array}$ & Groups & $\begin{array}{l}\text { Aerobic } \\
\text { Capacity }\end{array}$ & $\begin{array}{c}\text { Lower-Limb } \\
\text { Strength }\end{array}$ & $\begin{array}{l}\text { Upper-Limb } \\
\text { Strength }\end{array}$ & $\begin{array}{c}\text { Abdominal } \\
\text { Performance }\end{array}$ \\
\hline \multirow[t]{2}{*}{ IL- $1 \beta$} & Control & $\begin{array}{c}\mathrm{r}=-0.3820 \\
\mathrm{P}=0.072\end{array}$ & $\begin{array}{c}\mathrm{r}=-0.1820 \\
\mathrm{P}=0.3878\end{array}$ & $\begin{array}{c}r=0.6032 \\
P=0.0103\end{array}$ & $\begin{array}{c}\mathrm{r}=-0.0106 \\
\mathrm{P}=0.9618\end{array}$ \\
\hline & $\begin{array}{l}\text { Parasitic } \\
\text { infection }\end{array}$ & $\begin{array}{c}\mathrm{r}=-0.3565 \\
\mathrm{P}=0.1601\end{array}$ & $\begin{array}{c}\mathrm{r}=-0.1169 \\
\mathrm{P}=0.6549\end{array}$ & $\begin{array}{l}\mathrm{r}=0.0727 \\
\mathrm{P}=0.7817\end{array}$ & $\begin{array}{c}r=-0.0386 \\
P=0.8832\end{array}$ \\
\hline \multirow[t]{2}{*}{ IL-6 } & Control & $\begin{array}{c}\mathrm{r}=-0.1869 \\
\mathrm{P}=0.3931\end{array}$ & $\begin{array}{c}\mathrm{r}=-0.2117 \\
\mathrm{P}=0.3322\end{array}$ & $\begin{array}{c}\mathrm{r}=-0.3330 \\
\mathrm{P}=0.1204\end{array}$ & $\begin{array}{c}r=0.2885 \\
\mathrm{P}=0.1818\end{array}$ \\
\hline & $\begin{array}{l}\text { Parasitic } \\
\text { infection }\end{array}$ & $\begin{array}{l}\mathrm{r}=0.1340 \\
\mathrm{P}=0.6207\end{array}$ & $\begin{array}{c}\mathrm{r}=-0.0356 \\
\mathrm{P}=0.8959\end{array}$ & $\begin{array}{l}\mathrm{r}=0.2505 \\
\mathrm{P}=0.3493\end{array}$ & $\begin{array}{c}r=-0.1632 \\
P=0.5459\end{array}$ \\
\hline \multirow[t]{2}{*}{ IL-8 } & Control & $\begin{array}{l}\mathrm{r}=0.1402 \\
\mathrm{P}=0.5234\end{array}$ & $\begin{array}{c}\mathrm{r}=-0.1097 \\
\mathrm{P}=0.6182\end{array}$ & $\begin{array}{c}\mathrm{r}=-0.2369 \\
\mathrm{P}=0.2765\end{array}$ & $\begin{array}{l}r=0.4439 \\
P=0.0338\end{array}$ \\
\hline & $\begin{array}{l}\text { Parasitic } \\
\text { infection }\end{array}$ & $\begin{array}{l}r=0.5906 \\
P=0.0455\end{array}$ & $\begin{array}{c}\mathrm{r}=-0.3190 \\
\mathrm{P}=0.2120\end{array}$ & $\begin{array}{c}\mathrm{r}=-0.0676 \\
\mathrm{P}=0.7965\end{array}$ & $\begin{array}{l}\mathrm{r}=0.0515 \\
\mathrm{P}=0.8744\end{array}$ \\
\hline \multirow[t]{2}{*}{ IL-10 } & Control & $\begin{array}{c}r=0.1366 \\
P=0.5343\end{array}$ & $\begin{array}{c}\mathrm{r}=0.0825 \\
\mathrm{P}=0.7084\end{array}$ & $\begin{array}{c}\mathrm{r}=-0.1254 \\
\mathrm{P}=0.5685\end{array}$ & $\begin{array}{l}\mathrm{r}=0.1399 \\
\mathrm{P}=0.5244\end{array}$ \\
\hline & $\begin{array}{l}\text { Parasitic } \\
\text { infection }\end{array}$ & $\begin{array}{c}\mathrm{r}=-0.2854 \\
\mathrm{P}=0.2668\end{array}$ & $\begin{array}{c}\mathrm{r}=0.3830 \\
\mathrm{P}=0.1291\end{array}$ & $\begin{array}{l}r=0.1149 \\
\mathrm{P}=0.6604\end{array}$ & $\begin{array}{c}\mathrm{r}=-0.2113 \\
\mathrm{P}=0.4156\end{array}$ \\
\hline \multirow[t]{2}{*}{ IL-12 } & Control & $\begin{array}{c}\mathrm{r}=-0.2524 \\
\mathrm{P}=0.2452\end{array}$ & $\begin{array}{c}r=-0.4670 \\
P=0.0246\end{array}$ & $\begin{array}{c}\mathrm{r}=-0.3543 \\
\mathrm{P}=0.0971\end{array}$ & $\begin{array}{c}\mathrm{r}=-0.1555 \\
\mathrm{P}=0.4787\end{array}$ \\
\hline & $\begin{array}{l}\text { Parasitic } \\
\text { infection }\end{array}$ & $\begin{array}{c}\mathrm{r}=-0.0164 \\
\mathrm{P}=0.8149\end{array}$ & $\begin{array}{l}\mathrm{r}=0.0455 \\
\mathrm{P}=0.8625\end{array}$ & $\begin{array}{c}\mathrm{r}=-0.2787 \\
\mathrm{P}=0.2786\end{array}$ & $\begin{array}{l}\mathrm{r}=0.0152 \\
\mathrm{P}=0.9538\end{array}$ \\
\hline \multirow[t]{2}{*}{ IL-17 } & Control & $\begin{array}{l}\mathrm{r}=0.0911 \\
\mathrm{P}=0.6867\end{array}$ & $\begin{array}{c}\mathrm{r}=-0.1856 \\
\mathrm{P}=0.4083\end{array}$ & $\begin{array}{c}\mathrm{r}=0.1000 \\
\mathrm{P}=0.9100\end{array}$ & $\begin{array}{l}\mathrm{r}=0.3335 \\
\mathrm{P}=0.1293\end{array}$ \\
\hline & $\begin{array}{l}\text { Parasitic } \\
\text { infection }\end{array}$ & $\begin{array}{c}\mathrm{r}=-0.1030 \\
\mathrm{P}=0.7502\end{array}$ & $\begin{array}{c}\mathrm{r}=-0.2544 \\
\mathrm{P}=0.4248\end{array}$ & $\begin{array}{c}\mathrm{r}=-0.1129 \\
\mathrm{P}=0.7269\end{array}$ & $\begin{array}{c}r=0.6014 \\
P=0.0385\end{array}$ \\
\hline \multirow[t]{2}{*}{ TNF- $\alpha$} & Control & $\begin{array}{c}\mathrm{r}=-0.3727 \\
\mathrm{P}=0.0798\end{array}$ & $\begin{array}{c}\mathrm{r}=0.0252 \\
\mathrm{P}=0.9091\end{array}$ & $\begin{array}{c}\mathrm{r}=-0.0122 \\
\mathrm{P}=0.9560\end{array}$ & $\begin{array}{c}\mathrm{r}=-0.1943 \\
\mathrm{P}=0.3743\end{array}$ \\
\hline & $\begin{array}{l}\text { Parasitic } \\
\text { infection }\end{array}$ & $\begin{array}{c}\mathrm{r}=-0.1655 \\
\mathrm{P}=0.5256\end{array}$ & $\begin{array}{c}\mathrm{r}=-0.1730 \\
\mathrm{P}=0.5067\end{array}$ & $\begin{array}{c}\mathrm{r}=-0.2139 \\
\mathrm{P}=0.4097\end{array}$ & $\begin{array}{c}r=0.4309 \\
P=0.0481\end{array}$ \\
\hline
\end{tabular}

In the acute phase of infection, there is an elevation in the cellular response, whereas in the chronic phase, there is a reduction of this immune response. In this study, we observed a proinflammatory response (Th1) with increased IL-12 and TNF- $\alpha$ in the serum of students with parasitic infection. These cytokines are involved in the eradication of various infectious diseases (Vernal $e t a l$., 2008; Heo et al., 2010).

Studies have reported that TNF- $\alpha$ can modulate helminth infections by regulating the expression of IL- 4 and IL-13 receptors in the cells of the intestinal microenvironment (Lugli et al., 1997), and it is believed that this cytokine regulates the responses of Th2 cytokines in the intestine and exerts a significant effect on the protective immunity to parasitic infection due to complex interactions in the cytokine network (Artis et al., 1999).

In this study, parasitic infection reduced IL-8 in the serum of school children. IL-8 is a chemokine that is related to a variety of diseases. It has the ability to promote the migration of cells such as neutrophils, monocytes and $\mathrm{T}$ cells and increases inflammation (Pepper, 1997). This chemokine is capable of reducing the production of $\operatorname{IgE}$ stimulated by IL-4 (Baggiolini et al., 1994). Considering that IgE is an important part of the immune mechanism for the elimination of helminths, the reduction of IL-8 in the serum of parasitized school children suggests an 


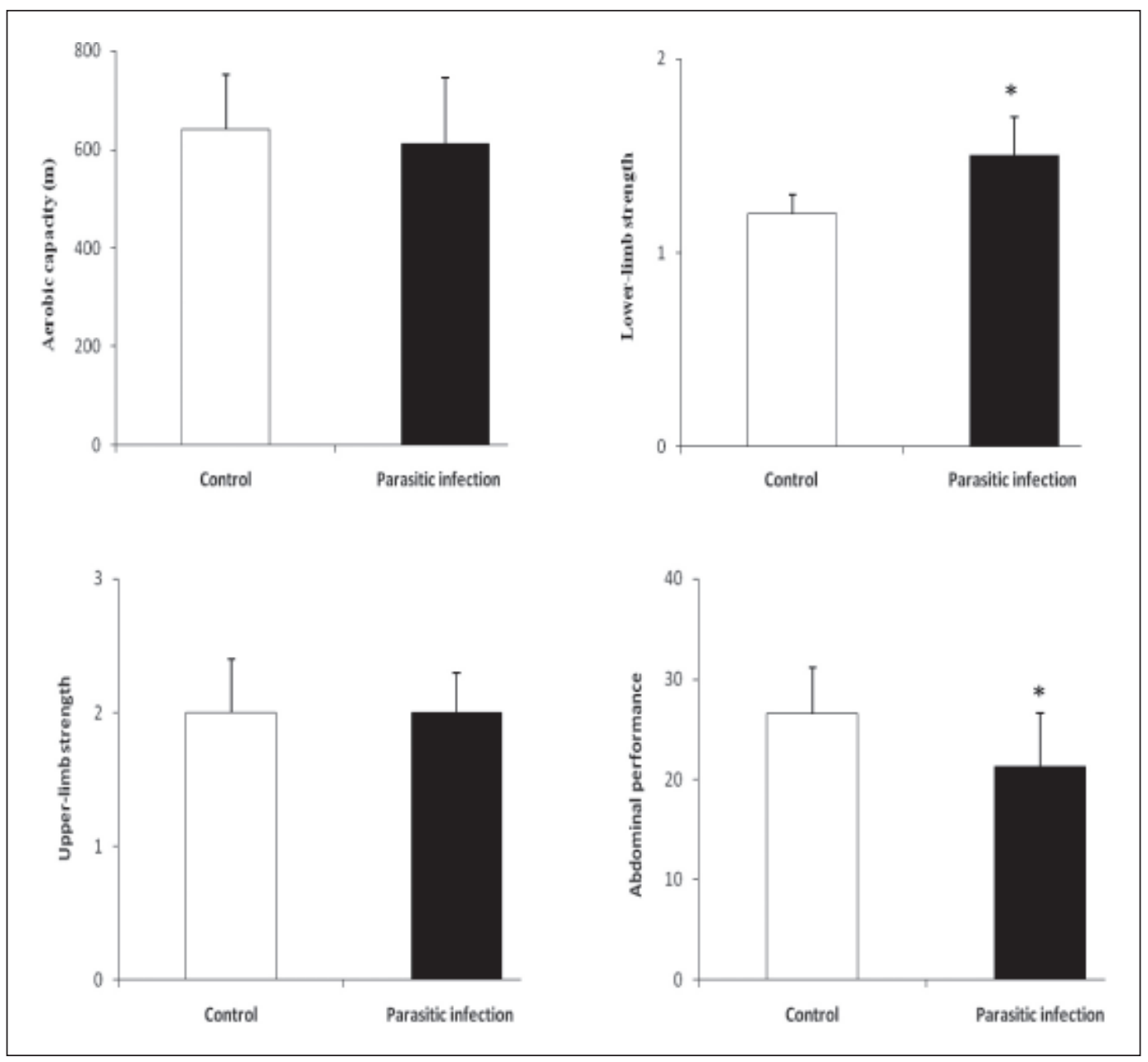

Figure 2. Aerobic capacity (A), lower-limb strength (B), upper-limb strength (C) and abdominal performance (D) of school children with positive parasitological examinations. The results represent the mean and the standard error. $\mathrm{P}<0.05$.

immunological control mechanism targeting an increase in IgE-mediated responses and favouring the elimination of the parasites.

Interactions among cytokines and hormones have been reported in several studies. Elevated levels of melatonin in the blood have been associated with increased IL-12 (García-Mauriño, 1999). In this work, in addition to the increased IL-12 and TNF- $\alpha$, high concentrations of the hormone melatonin were found in the serum of parasitized school children.

Melatonin exerts several functions in the body and has been extensively studied (Maestroni, 2001; Srinivasan et al., 2008; França-Botelho et al., 2011; Hara et al., 2013; Honorio-França et al., 2013). The beneficial actions of melatonin are associated with its ability to remove free radicals and increase the activity of antioxidant enzymes (Sudnikovich et al., 2007; Pandi-Perumal et al., 2008). In addition, melatonin has immunomodulatory effects (Besedovsky $e t$ al.,1996; Honorio-França et al., 2013; Hara et al., 2013; Pereira et al., 2018) and reduces the severity of E. histolytica (FrançaBotelho et al., 2011) and T. cruzi (Santelo et al., 2007) infections, suggesting effective therapeutic action in the treatment of these protozoa.

Due to the anti-inflammatory properties of melatonin (Reiter et al., 1995; Morceli et $a l ., 2013)$, the increase in this hormone in the serum of parasitized school children may 
reduce the inflammatory effects of the cytokines IL-12 and TNF- $\alpha$, which explains the modulation of the immune response and tissue protection during infection (CarrilloVico et al., 2004; Fernandes et al., 2006), in addition to inhibiting the hormone cortisol (Gunn et al., 2016). Cortisol is an important hormone in the inflammatory process (Fagundes et al., 2012) and immune response (Bonga, 1997; Fagundes et al., 2012).

Children of low socioeconomic status are part of a vulnerable group of risk due to the stressful experience early in life, which can cause a cortisol dysregulation. In this study, the presence of parasites did not alter the levels of this hormone, which reinforces the hypothesis that the increase in melatonin reduces cortisol levels.

Interestingly, the hormone cortisol had a negative correlation with IL-17. There is a close relationship between hormones, cytokines and neuropeptides that modulate the host immune response, including both cellular and humoral immunity (AguilarDíaz et al., 2015). During many parasitic infections, there is a reciprocal relationship amongst hormones, the immune system, and the eventual elimination or establishment of the parasites in humans (Hernández-Bello et al., 2010). Both cortisol (Fagundes et al., 2012) and IL-17 (Papu et al., 2012) appear to be involved in inflammatory processes. In malaria, IL-17 plays an important role (Scherer et al., 2016), but further studies should be conducted to investigate the effects of the interaction of this cytokine and cortisol.

Additionally, in this work, a positive correlation between melatonin and IL-12 was observed in students with parasitic infection, suggesting that in the presence of infection, melatonin interacts with mediators of inflammation. In the literature, other studies have also reported that melatonin may modulate mediators of inflammation (García-Mauriño et al., 1999; Carrillo-Vico et al., 2004; Fernandes et al., 2006).

Inflammation is a physiological response of the immune system to infectious agents or tissue damage. A previous study reported that physical exercise may have anti- or proinflammatory effects and may protect or expose the body to the development of various chronic and infectious diseases (Warren $e t$ al., 2010).

The responses promoted by exercise, both acute and chronic, change various immunological parameters. Moderate exercise may stimulate cellular immunity and thereby decrease the risk of infection, while high-intensity exercise may promote a decrease in the immune system and increase the risk of infectious diseases (Pedersen et al., 2000).

In this study, the physical performance of students, regardless of the presence of parasites, was similar with regard to aerobic capacity and upper-limb strength. However, students with parasitic infections, despite having greater muscle strength of the lower limbs, had a reduction in abdominal performance. As these students were mostly infected with helminths, this reduction in abdominal performance may be a direct effect of parasitic infection.

It should also be considered that despite the presence of parasites, these children presented normal physical growth data, which may have contributed to maintaining reasonable physical performance, since studies suggest that well-nourished children with nutrient reserves are less susceptible to the harmful effects of parasites (Lazarte $e t$ al., 2015).

Serum levels of cytokines can be modulated by various stimuli, including hormones, oxidative stress, and exercise (Cannon, 2000). Several studies have reported increased serum cytokine levels after different forms of exercise (Terra et al., 2012). In this study, cytokines and physical performance were correlated. It was observed in the parasitized group that there was a positive correlation between IL- 8 and aerobic capacity and between IL-17/TNF $\alpha$ and abdominal performance.

IL-8 promotes increased oxidative metabolism (Zwahlen et al., 1993) and is normally stimulated by $\mathrm{TNF} \alpha$ (Baggiolini et al., 1994) and by IL-17 (Fossiez, 1996). $\mathrm{TNF} \alpha$ also promotes increases in oxidative metabolism and helps in the production of 
proteins (Mackay et al., 1993; Tartaglia et al., 1993), and in individuals with high physical performance, there is a decrease in this cytokine (Bruunsgaard, 2005).

Therefore, according to the data of this study, it can be suggested that parasitic infection influenced abdominal performance, since the parasitized group presented lower abdominal performance and a correlation between abdominal performance and IL-17 and TNF $\alpha$. Studies have reported that one of the clinical features of $S$. mansoni infestation is abdominal muscle pain (Huggins et al., 1998). Therefore, it is likely that the concentration of TNF $\alpha$ is elevated, inducing an acute inflammatory process in the combat against parasitic infection (Willerson et al., 2004). However, further studies are needed to better understand the effects on physical capacity in children with parasites.

Interaction between exercise and hormones has also been reported, and studies suggest that melatonin may have a favourable influence on many systems in the body (Escames et al., 2010). Melatonin, as well as the immune system, acts as a regulatory factor and appears to inhibit inflammation in an intensity-dependent manner during exercise. Melatonin levels increase after exercise in a transient and short-term process, but a decrease or no change in the amount of melatonin has also been reported after exercise (Beck et al., 2016; Zarei et al., 2016). In this study, both melatonin and cortisol were correlated with physical exercise, but the correlation was independent of the presence of parasites.

In conclusion, these data suggest that parasitic infections determine a profile of inflammatory cytokines and that melatonin, due to its anti-inflammatory properties, could be involved in the control of this process to minimize tissue damage. The difficulty of the students in practising physical exercises, especially those regarding abdominal performance should be considered, since this difficulty can be an indication of enteroparasitic infection. Therefore, physical educators should be informed so that they can observe these difficulties and guide students to undergo parasitological examinations.

Acknowledgments. This work was supported by the Conselho Nacional de Desenvolvimento Científico e Tecnológico (CNPq), Brazil, the Fundação de Apoio a Pesquisa de Mato Grosso (FAPEMAT), Brazil, and the Coordenação de Aperfeiçoamento de Pessoal de Nível Superior (CAPES), Brazil.

\section{REFERENCES}

Aguilar-Díaz, H., Nava-Castro, K.E., CerbónCervantes, M.A., Meneses-Ruiz, D.M., Ponce-Regalado, M.D. \& Morales-Montor, J. (2015). Endocrine Immune Interactions in the Host-Parasite Relationship: Steroid Hormones as Immune Regulators in Parasite Infections. Journal of Steroids and Hormonal Science 6: 165-176.

Araújo Filho, H.B., Carmo-Rodrigues, M.S., Mello, C.S., Melli, L.C.F.L., Tahan, S. \& Morais, M.B. (2011). Intestinal parasitoses are associated with lower values of weight and height in school-aged children from low socioeconomic level. Revista Paulista de Pediatria 29: 521528.

Araujo, M.I., Hoppe, B.S., Medeiros Jr, M. \& Carvalho, E.M. (2004). Schistosoma mansoni infection modulates the immune response against allergic and auto-immune diseases. Memórias do Instituto Oswaldo Cruz 99: 27-32.

Artis, D., Potten, C.S., Else, K.J., Finkelman, F.D. \& Grencis, R.K. (1999). Trichuris muris: host intestinal epithelial cell hyperproliferation during chronic infection is regulated by interferongamma. Experimental Parasitology 92: 144-153.

Baggiolini, M., Dewald, B. \& Moser, B. (1994). Interleukin 8 and related chemotactic cytokines - CXC and CC chemokines. Advanced of Immunology 55: 97-109.

Baggiolini, M. (2001). Chemokines in pathology and medicine. Journal of Internal Medicine 250: 91-104. 
Basso, R.M., Silva-Ribeiro, R.T., Soligo, D.S., Ribacki, S.I., Callegari-Jacques, S.M. \& Zoppas, B.C. (2008). Evolution of the prevalence of intestinal parasitosis among school children in Caxias doSul, RS. Revista da Sociedade Brasileira de Medicina Tropical 41: 263-268.

Beck, W.R., Scariot, P.P. \& Gobatto, C.A. (2016). Melatonin is an ergogenic aid for exhaustive aerobic exercise only during the wakefulness period. International Journal of Sports Medicine 37: 71-76.

Besedovsky, H.O. \& del Rey, A. (1996). Immune-neuro-endocrine interactions: facts and hypotheses. Endocrine Reviews 17: 64-102.

Bonga, W.S.E. (1997). The stress response in fish. Physiological Reviews 77: 591-625.

Bruunsgrard, H. (2005). Physical activity modulation of systemic low-level inflammation. Journal Leukocytes Biology 78: 819-835.

Cannon, G.W. (2000). Rofecoxib, a specific inhibitor of cyclooxygenase 2, with clinical efficacy comparable with that of diclofenac sodium: results of a one-year, randomized, clinical trial in patients with osteoarthritis of the knee and hip. Rofecoxib phase III protocol 035 study group. Arthritis \& Rheumatology 43: 978-987.

Carrillo-Vico, A., Calvo, J.R., Abreu, P., Lardone, P.J., García-Mauriño, S., Reiter, R.J. \& Guerrero, J.M. (2004). Evidence of melatonin synthesis by human lymphocytes and its physiological significance: possible role as intracrine, autocrine, and/or paracrine substance. The FASEB Journal 18: 537-539.

Escames, G., López, A., García, J.A., García, L., Acuña-Castroviejo, D., García, J.J. \& López, L.C. (2010). The Role of Mitochondria in Brain Aging and the Effects of Melatonin. Current Neuropharmacology 8: 182-193.
Fagundes, D.L.G., França, E.L., Hara, C.C.P. \& Honorio-França, A.C. (2012). Immunomodulatory effects od Poly (Ethylene Glycol) microsphers adsorved with cortisol os activity of colostrum phagocytes. International Journal of Pharmacology 8: 510-518.

Fagundes, D.L.G., França, E.L., Fernandes, R.T.S., Hara, C.C.P., Morceli, G., HonorioFrança, A.C. \& Calderon, I.M.P. (2016). Changes in T cell phenotype and cytokines profile in maternal blood, cord blood and colostrum of diabetic mothers. Journal Maternal Fetal and Neonatal Medicine 29: 998-1004.

Fagundes, D.L.G., França, E.L., Gonzatti, M.B., Rudge, M.V.C., Calderon, I.M.P. \& HonorioFrança, A.C. (2018). The modulatory role of cytokines IL- 4 and IL-17 in the functional activity of phagocytes in diabetic pregnant women. Acta Pathologica, Microbiologica et Immunologica Scandinavica 126: 56-64.

Fernandes, P.A.C.M., Cecon, E., Markus, R.P. \& Ferreira, Z.S. (2006). Effect of TNF- $\alpha$ on the melatonin synthetic pathway in the rat pineal gland: Basis for a "feedback" of the immune response on circadian timing. Journal of Pineal Research 41: 344-350.

Ferreira, F.C., de Medeiros, A.I., Nicioli, C., Nunes, J.E., Shiguemoto, G.E., Prestes, J., Verzola, R.M., Baldissera, V. \& Perez, S.E. (2009). Circuit resistance training in sedentary women: body composition and serum cytokine levels. Applied Physiology, Nutrition and Metabolism 35: 23-29.

Fossiez, F.T. (1996). Cell interleukin-17 induces stromal cells to produce proinflammatory and hematopoietic cytokines. Journal Experimental Medicine 183: 2593-2603.

França-Botelho, A.C., França, J.L., Oliveira, F.M.S., França, E.L., Honorio-França, A.C., Caliari, M.V. \& Gomes, M.A. (2011). Melatonin reduces the severity of experimental amoebiasis. Parasites \& Vectors 4: e62. 
Frei, F., Jumcansen, C. \& Ribeiro-Paes, J.T. (2008). Epidemiological survey of intestinal parasite infections: analytical bias due to prophylactic treatment. Cadernos de Saúde Pública 24: 29192925.

Fujimori, M., França, E.L., Moraes, T.C., Fiori, V., de Abreu, L.C. \& Honório-França, A.C. (2017). Cytokine and adipokine are biofactors can act in blood and colostrum of obese mothers. Biofactors 23: 45-51.

García-Mauriño, S., Pozo, D., Carrillo-Vico, A., Calvo, J.R. \& Guerrero, J.M. (1999). Melatonin activates Th1 lymphocytes by increasing IL-12 production. Life Science 65: 2143-2150.

Gleeson, M., McFarlin, B. \& Flynn, M. (2006). Exercise and Toll-like receptors. Exercise Immunology Reviews 12: 3453.

Gordon, C.C., Chumlea, W.C. \& Roche, A.F. (1991). Stature, recumbent length, and weight. In: Anthropometric Standardization Reference Manual, Lohman, T.G., Roche, A.F. \& Martorell, R. (Editors) First Edition. Champaign, Illinois: Human Kinetics Books, pp. 3-8.

Guerrant, D.I., Moore, S.R., Lima, A.A.M., Patrick, P.D., Schorling, J.B. \& Guerrant, R.L. (1999). Association of early childhood diarrhea and cryptosporidiosis with impaired physical fitness and cognitive function four-seven years later in a poor urban community in northeast Brazil. The American Journal of Tropical Medicine and Hygiene 61: 707-713.

Gunn, P.G., Middleton, B., Davies, S.K., Revell, V.L. \& Skene, D.J. (2016). Sex differences in the circadian profiles of melatonin and cortisol in plasma and urine matrices under constant routine conditions. Chronobiology Internation 33: 39-50.

Hara, C.C.P., Honorio-França, A.C., Fagundes, D.L.G., Guimarães, P.C.L. \& França, E.L. (2013). Melatonin nanoparticles adsorbed to polyethylene glycol microspheres as activators of human colostrum macrophages. Journal of Nanomaterials 2013: 1-8.
Heo, Y.J., Joo, Y.B., Oh, H.J., Park, M.K., Heo, Y.M., Cho, M.L., Kwok, S.K., Ju, J.H., Park, K.S., Cho, S.G., Park, S.H., Kim, H.Y. \& Min, J.K. (2010). IL-10 suppresses Th17 cells and promotes regulatory $\mathrm{T}$ cells in the CD4+ T cell population of rheumatoid arthritis patients. Immunology Letters 127: $150-156$

Hernández-Bello, R., Escobedo, G., Guzmán, C., Ibarra-Coronado, E.G., López-Griego, L. \& Morales-Montor, J. (2010). Immunoendocrine host-parasite interactions during helminth infections: from the basic knowledge to its possible therapeutic applications. Parasite Immunology 32: 633-643.

Hijjar, M.A., Procopio, M.J., Freitas, L.M.R., Guedes, R. \& Bethelm, E.P. (2005). Epidemiology of tuberculosis in the world, Brasil and Rio de Janeiro. Pulmão 14: 310-314.

Hoeger, W.W.K. \& Hopkins, D.R. (1992). A comparison of the sit and reach and the modified sit and reach in measurement of flexibility in women. Research Quarterly for Exercise and Sport 63: 191-195.

Hoffman, W.A., Pons, J.A. \& Janer, J.L. (1934). Sedimentation concentration method in Schistosomiasis mansoni. Journal of Public Health and Tropical 9: 283-298.

Honorio-França, A.C., Hara, C.C.P., Ormonde, J.V.S., Nunes, G.T. \& França, E.L. (2013). Human colostrum melatonin exhibits a day-night variation and modulates the activity of colostral phagocytes. Jourmal of Applied Biomedicine 11: 153-162.

Huggins, D.W., Medeiros, L.B. \& SiqueiraBatista, R. (1998). Evolução clínica. In: Esquistossomose mansoni, Huggins, D.W., Siqueira-Batista, R. \& Medeiros, L.B. (Editors) First Edition. São Paulo: Grupo Editorial Moreira Jr, pp. 56-74.

Katz, N., Chaves, A. \& Pelegrino, J. (1972). Asimple device for quantitative stool thick-smear technique in schistosomiasis mansoni. Revista do Instituto de Medicina Tropical 14: 397-400. 
Lander, R.L. (2012). Factors influencing growth and intestinal parasitic infections in preschoolers attending philanthropic daycare centers in Salvador, Northeast Region of Brazil. Cadernos de Saúde Pública 28: 2177-2188.

Lazarte, C.E., Soto, A., Alvarez, L., Bergenståh, B., Medrano, N. \& Granfeldt, Y. (2015). Nutritional status of children with intestinal parasites ffrom tropical area of Bolivia. Emphasis on zinc and iron status. Food Nutrition Science 6: 399411.

Lugli, S.M., Feng, N., Heim, M.H., Adam, M., Schnyder, B., Etter, H., Yamage, M., Eugster, H.P., Lutz, R.A., Zurawski, G. \& Moser, R. (1997). Tumor necrosis factor alpha enhances the expression of the interleukin (IL)-4 receptor alpha-chain on endothelial cells increasing IL-4 or IL- 13induced Stat6 activation. Journal of Biological Chemistry 272: 5487-5494.

Mackay, F., Loester, H., Stueber, D., Gehr, G. \& Les-Slaur, W. (1993). Tumor necrosis factor alpha (TNF- $\alpha)$-induced cell adhesion to human endotelial cells is under dominant control of one TNF receptor type, TNF-R55. Journal Experimental Medicine 177: 1277-1286.

Maestroni, G.S. (2001). The immunotherapeutic potential of melatonin. Expert Opinion on Investigational Drugs 10: 467-476.

Martinez-Bakker, M. \& Helm, B. (2015). The influence of biological rhythms on hostparasite interactions. Trends in Ecology \& Evolution 30: 314-326.

Montresor, A., Crompton, D.W., Gyorkos, T.W. \& Savioli, L. (2002). Helminth control in school-age children: a guide for managers of control programmes. Geneva: World Health Organization. pp. 1-84.

Morais, T.C., Honorio-França, A.C., Silva, R.R., Fujimori, M., Fagundes, D.L.G. \& França, E.L. (2015). Temporal fluctuations of cytokine concentrations in human milk. Biological Rhythm Research 46 : $1-20$.
Morceli, G., Honorio-França, A.C., Fagundes, D.L.G., Calderon, I.M.P. \& França, E.L. (2013). Antioxidant Effect of Melatonin on the Functional Activity of Colostral Phagocytes in Diabetic Women. PLos One 8: 56915.

Muller, V., Coulibaly, J.T., Furst, T., Knopp, S., Hattendorf, J., Krauth, S.J., Stete, K., Righetti, A.A., Glinz, D., Yao, A.K., Pühse, U., N'Goran, E.K. \& Utzinger, J. (2011). Effect of Schistosomiasis and SoilTransmitted Helminth Infections on Physical Fitness of School Children in Côte d'Ivoire. PLOS Neglected Tropical Diseases 5: e1239.

Ostan, I., Kilimcioğlu, A.A., Girginkardeşler, N., Ozyurt, B.C., Limoncu, M.E. \& Ok, U.Z. (2007). Health inequities: lower socio-economic conditions and higher incidences of intestinal parasites. $B M C$ Public Health 7: e342.

Pandi-Perumal, S.R., Trakht, I., Srinivasan, V., Spence, D.W., Maestroni, G.J.M. \& Zisapel, N. (2008). Physiological effects of melatonin: Role of melatonin receptors and signal transduction pathways. Progress in Neurobiology 85: 335-353.

Papu, R., Rutz, S. \& Ouyang, W. (2012). Regulation of epithelial immunity by IL-17 family cytokines. Trends Immunology 3: 343-349.

Pedersen, B.K. \& Toft, A.D. (2000). Effects of exercise on lymphocytes and cytokines. British Journal of Sports Medicine 34: 246-251.

Pepper, M.S. (1997). Transforming growth factor- $\beta$ : vasculogenesis, angiogenesis, and vessel wall integrity. Cytokine \& Growth Factor Reviews 8: 21-43.

Pereira, Q.L., Hara, C.C.P., Fernades, R.T.S., Fagundes, D.L.G., França-Botelho, A.C., Gomes, M.A., França, E.L. \& HonorioFrança, A.C. (2018). Human colostrum action against Giardia lamblia infection influenced by hormones and advanced maternal age. Parasitology Research 117: 1783-1791. 
Quintanar-Stephano, A., HernandezCervantes, R., Moreno-Mendoza, N., Escobedo, G., Carrero, J.C., Nava-Castro, K.E. \& Morales-Montor, J. (2015). The endocrine e immune network during taeniosis by Taenia solium: the role of the pituitary gland. Experimental Parasitology 159: 233-244.

Reiter, R.J. (1995). Oxidative processes and antioxidative defense mechanisms in the aging brain. FASEB Journal 9: 526-533.

Santello, F.H., Frare, E.O., Caetano, L.C., Alonso-Toldo, M.P. \& do Prado, J.C. (2008a). Melatonin enhances proinflammatory cytokine levels and protects against Chagas disease. Journal of Pineal Research 45: 79-85.

Santello, F.H., Frare, E.O., dos Santos, C.D., Caetano, L.C., Alonso-Toldo, M.P. \& do Prado, J.C. (2008b). Suppressive action of melatonin on the TH-2 immune response in rats infected with Trypanosoma cruzi. Journal of Pineal Research 45: 291-296.

Santello, F.H., Frare, E.O., dos Santos, C.D., Alonso-Toldo, M.P., Kawasse, L.M., Zucoloto, S. \& Do Prado, J.C. (2007). Melatonin treatment reduces the severity of experimental Trypanosoma cruzi infection. Journal of Pineal Research 42: 359-363.

Scherer, E.F., Cantarini, D.G., Siqueira, R., Ribeiro, E.B., Braga, E.M., HonorioFrança, A.C. \& França, E.L. (2016). Cytokine modulation of human blood viscosity from vivax malaria patients. Acta Tropica 158: 139-147.

Soares, J. \& Sessa, M. (1983). Medidas da força muscular. In: Matsudo VKR. $2^{\mathrm{a}}$ Ed. Testes em Ciências do Esporte. São Paulo: Burti, p. 61-62.

Srinivasan, V., Spence, D.W., Pandi-Perumal, S.R., Trakht, I., Esquifino, A.I., Cardinali, D.P. \& Maestroni, G.J. (2008). Melatonin, environmental light, and breast cancer. Breast Cancer Research and Treatment 108: 339-350.
Stephenson, L.S., Latham, M.C., Kinoti, S.N. Kurz, K.M. \& Brigham, H. (1990). Improvements in physical fitness of Kenyan schoolboys infected with hookworm, Trichuris trichiura and Ascaris lumbricoides following a single dose of albendazole. Transactions of the Royal Society of Tropical Medicine and Hygiene 84: 277-282.

Stephenson, L.S., Latham, M.C., Adams, E.J., Kinoti, S.N. \& Brigham, H. (1993). Physical fitness, growth and appetite of Kenyan school boys with hookworm, Trichuris trichiura and Ascaris lumbricoides infections are improved four months after a single dose of albendazole. Journal of Nutrition 123: 1036-1046.

Sudnikovich, E.J., Maksimchik, Y.Z., Zabrodskaya, S.V., Kubyshin, V.L., Lapshina, E.A., Bryszewska, M., Reiter, R.J. \& Zavodnik, I.B. (2007). Melatonin attenuates metabolic disordens due to streptozotocin induced diabetes in rats. European Journal of Pharmacology 569: 180-187.

Tartaglia, L.A., Ayres, T.M., Wong, G.H. \& Goeddel, D.V. (1993). A novel domain within the $55 \mathrm{kd}$ TNF receptor signals cell death. Cell 74: 845-853.

Terra, R., Silva, S.A.G., Pinto, V.S. \& Dutra, P.M.L. (2012). Effect of exercise on immune system: response, adaptation and cell signaling. Exercise and Sports Science 18: 208-214.

Vernal, R., Velásquez, E., Gamonal, J., GarciaSanz, J.A., Silva, A. \& Sanz, M. 2008. Expression of proinflammatory cytokines in osteoarthritis of the temporomandibular joint. Archives of Oral Biology 53: 910-915.

Warren, G.L., Park, N.D., Maresca, R.D., Mckibans, K.I. \& Millard-Stafford, M.L. (2010). Effect of caffeine ingestion on muscular strength and endurance: a Meta analysis. Medicine \& Science in Sports \& Exercise 42: 1375-1387. 
Willerson, J.T. \& Ridker, P.M. (2004). Inflammation as a cardiovascular risk factor. Circulation 109: 2-10.

Yap, P., Du, Z.W., Chen, R., Zhang, L.P., Wu, F.W., Wang, J., Wang, X.Z., Zhou, H., Zhou, X.N., Utzinger, J. \& Steinmann, P. (2012). Soil-transmitted helminth infections and physical fitness in school-aged Bulang children in southwest China: results from a cross-sectional survey. Parasite \& Vectors 5: e50.

Zaldivar, F., Wang-Rodriguez, J., Nemet, D., Schwindt, C., Galassetti, P., Mills, P.J., Wilson, L.D. \& Cooper, D.M. 2005. Constitutive pro- and anti-inflammatory cytokine and growth factor response to exercise in leukocytes. Journal Applied Physiology 100: 1124-33.
Zarei, M., Barroso, E., Leiva, R., BarniolXicota, M., Pujol, E., Vázquez, C.E.S., Palomer, X., Pardo, V., GonzálezRodríguez, A., Valverde, A.M., QuesadaLópez, T., Villarroya, F., Wahli, W. \& Vázquez-Carrera, M. (2016). HemeRegulated eIF2 $\alpha$ Kinase Modulates Hepatic FGF21 and is Activated by PPARß/反 Deficiency. Diabetes 65: 31853199.

Zwahlen, R., Walz, A. \& Rot, A. (1993). In vitro and in vivo activity and pathophysiology of human interleukin- 8 and related peptides. International Review Experimental Pathology 34: 27-42. 